\title{
Pemilihan Desa Terbaik Di Kecamatan Pagar Merbau Menggunakan Metode Ahp
}

\author{
Ika Rara Pratiwi ${ }^{1}$, Arjon Samuel $\mathrm{Sitio}^{2}$, Anita Sindar ${ }^{3}$ \\ ${ }^{1,2,3}$ STMIK Pelita Nusantara Medan \\ ${ }^{1}$ rarascout14@gmail.com, 2arjonsitio@yahoo.com, ${ }^{3}$ haito_ita@yahoo.com \\ Jl. Iskandar Muda No.1, 20154 Medan Indonesia
}

\begin{abstract}
The empowerment of rural communities needs to be done institutional strengthening, increased motivation and self-help in community cooperation, so that in order to assess the success of village development, it is necessary to conduct a targeted, coordinated, integrated and sustainable assessment. with an assessment indicator. Village assessment is best done by comparing the latest development level based on village profile data in accordance with the assessment indicators. This study aims to build a decision support system to determine the best village based on the village assessment score using the Analytic Hierarchy Process (AHP) method. Basically, the decision-making process is to choose an alternative. The best village assessment consists of 6 criteria. The output of this system is the ranking of each village that has been assessed so as to produce recommendations for decision making in determining the best village. The highest total value of each row calculated by each sub-criteria is summed, the highest total value used is the basis for ranking the best village, Desa Pasar Miring with a final value $=0.969$.
\end{abstract}

\begin{abstract}
Abstrak - Pemberdayaan masyarakat desa perlu dilakukan penguatan kelembagaan, peningkatan motivasi dan swadaya gotong royong masyarakat didesa, sehingga untuk menilai keberhasilan pembangunan desa, perlu dilakukan penilaian secara terarah, terkoordinasi, terpadu dan berkelanjutan, untuk mendukung rencana pemerintah tersebut maka dilakukan kegiatan pelaksanaan penilaian desa terbaik, sesuai dengan indikator penilaian. Penilaian desa terbaik dilakukan dengan membandingkan tingkat perkembangan terakhir berdasarkan data profil desa sesuai dengan indikator penilaian. Penelitian ini bertujuan membangun sebuah sistem pendukung keputusan untuk menentukan desa terbaik berdasarkan skor penilaian desa dengan menggunakan metode Analytic Hierarchy Process (AHP). Pada dasarnya, proses pengambilan keputusan adalah memilih suatu alternatif. Penilaian desa terbaik terdiri dari 6 kriteria. Luaran dari sistem ini berupa rangking setiap desa yang telah dinilai sehingga menghasilkan rekomendasi untuk pengambilan keputusan dalam menentukan desa terbaik. Nilai total paling tinggi dari setiap baris hasil perhitungan setiap subkriteria dijumlahkan, Total Nilai Paling Tinggi digunakan merupakan dasar untuk merangking desa terbaik yaitu Desa Pasar Miring dengan Nilai Akhir = 0.969.
\end{abstract}

Keywords - AHP Method, Best Village, Ranking

\section{Pendahuluan}

Menurut Peraturan Pemerintah Nomor 72 Tahun 2005 tentang Desa, disebut bahwa desa adalah kesatuan masyarakat hukum yang memiliki batas-batas wilayah yang berwenang untuk mengatur dan mengurus kepentingan masyarakat setempat, berdasarkan asal usul dan adat istiadat setempat yang diakui dan dihormati dalam sistem pemerintahan Negara Kesatuan Republik Indonesia. Berbagai motivasi penilaian dilaksanakan pemerintah pada masyarakat desa guna memacu percepatan pembangunan yang merata. Keberhasilan desa didukung penuh seluruh masyarakat dengan perangkat desa [1]. Dalam upaya pemerintah melakukan pembangunan di daerah pedesaan untuk mewujudkan strategi pembangunan di dalam rencana pembangunan jangka menengah nasional 2015-2019, untuk mendukung rencana pemerintah, dilakukan kegiatan pelaksanaan penilaian desa terbaik.

Kegiatan pelaksanaan penilaian desa terbaik harus dilakukan dengan terbuka dan kompetitif meskipun jumlah data yang dimasukan relatif banyak tetapi keakuratan perhitungan serta laporan dapat dicapai semaksimal mungkin dan dengan efisiensi waktu dalam pengerjaan penyelesaian suatu laporan harus lebih baik. Penilaian desa terbaik sering terkendala, karena setiap desa memiliki karakteristik yang berbeda sehingga menyebabkan nilai kriteria pada masing-masing desa berbeda.

Perkembangan teknologi informasi dapat juga diterapkan dalam pemilihan desa terbaik. Sistem pengambil keputusan merupakan serangkaian tindakan dengan menerapkan salah satu metode Decision Support System (DSS) dalam menghasilkan sistem informasi interaktif yang menyediakan informasi, permodelan, dan pemanipulasian data. Sistem itu digunakan untuk membantu pengambilan keputusan dalam situasi yang semi terstruktur dan situasi yang tidak terstruktur [2]. Peralatan utama AHP adalah sebuah hierarki fungsional dengan input utamanya persepsi manusia. Keberadaan hierarki memungkinkan dipecahkan masalah kompleks atau tidak terstruktur dalam sub-sub masalah, lalu menyusunnya menjadi suatu bentuk hierarki [3].

Hasil penelitian sebelumnya membahas Pemilihan karyawan baru dengan Metode AHP (Analytic Hierarchy Process), dijelaskan bagaimana sistem pendukung 
keputusan ini dirancang menggunakan metode AHP untuk menghitung hasil dalam pemilihan karyawan baru.

\section{Metode Penelitian}

\section{A. Analisa Data}

Kecamatan Pagar Merbau, terdiri dari beberapa desa: Pasar Miring, Jati Rejo, Sidodadi Batu 8, Tanjung Mulia, Purwodadi dan Sukamulia. Dari hasil wawancara dibentuk Data kriteria desa terbaik terdiri dari bidang: pendidikan masyarakat, kesehatan masyarakat, ekonomi masyarakat, keamanan dan ketertiban, pemerintahan, lembaga kemasyarakatan dan pemberdayaan kesejahteraan keluarga.

\section{B. Analisa Sistem}

Setelah menentukan kriteria desa terbaik, sesuai SPK Metode AHP, selanjutnya menentukan matriks perbandingan berpasangan yang menggambarkan kontribusi relatif atau pengaruh setiap elemen terhadap masing-masing kriteria dengan kriteria lainnya.

\section{Implementasi Sistem}

Setelah melakukan perancangan SPK sesuai Metode AHP yang sesuai dengan kebutuhan dalam pemilihan desa terbaik di Kecamatan Pagar Merbau. berikutnya perancangan implementasi antarmuka dengan HIPO diagram, Gambar 1.

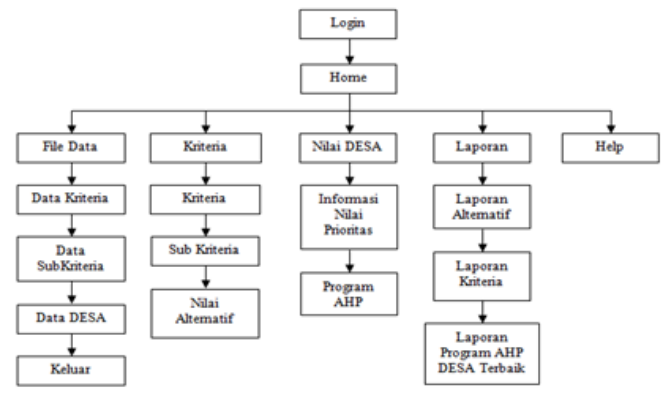

GAMBAR 1. HIPO DIAGRAM

Rancangan Metode AHP dalam aplikasi SPK, seorang user, setelah login, memilih menu File Data, memilih Data Kriteria, memilih Data Desa. User menginput data Kriteria, data Subkriteria, dan menentukan nilai alternatif. Tahap penilaian, dimulai memilih desa, dari perhitungan AHP diperoleh Informasi Nilai Prioritas.

\section{Hasil dan Pembahasan}

\section{A. Matriks Perbandingan}

Setelah menentukan kriteria dalam menentukan program Sistem Pendukung Keputusan Pemilihan Desa Terbaik di Tingkat Kecamatan maka langkah selanjutnya Membuat matriks perbandingan berpasangan yang menggambarkan kontribusi relatif atau pengaruh setiap elemen terhadap masing-masing kriteria dengan kriteria lainnya.
TABEL I

SKALA PENILAIAN PERBANDINGAN BERPASANGAN

\begin{tabular}{|c|l|}
\hline $\begin{array}{c}\text { Intensitas } \\
\text { Kepentingan }\end{array}$ & \multicolumn{1}{|c|}{ Keterangan } \\
\hline 1 & Kedua elemen sama pentingnya \\
\hline 3 & $\begin{array}{l}\text { Elemen yang satu sedikit lebih penting } \\
\text { daripada elemen yang lainnya }\end{array}$ \\
\hline 5 & $\begin{array}{l}\text { Elemen yang satu lebih penting daripada yang } \\
\text { lainnya }\end{array}$ \\
\hline 7 & $\begin{array}{l}\text { Satu elemen jelas lebih mutlak penting } \\
\text { daripada elemen lainnya }\end{array}$ \\
\hline 9 & $\begin{array}{l}\text { Satu elemen mutlak penting daripada elemen } \\
\text { lainnya }\end{array}$ \\
\hline $2,4,6,8$ & $\begin{array}{l}\text { Nilai-nilai antara dua nilai pertimbangan- } \\
\text { pertimbangan yang berdekatan }\end{array}$ \\
\hline
\end{tabular}

Penghitungan konsistensi logis dengan mengalikan matriks dengan prioritas bersesuaian:

1. Menjumlahkan hasil kali per baris.

2. Hasil penjumlahan tiap baris dibagi prioritas bersangkutan dan hasilnya dijumlahkan.

3. Hasil poin 2 dibagi jumlah elemen, didapatkan $\lambda$ Maks.

4. $C I=\frac{\lambda \text { Maks }-\mathrm{n}}{\mathrm{n}}$

5. Index Konsistensi

$$
C R=\frac{C I}{R I}
$$

6. Rasio konsistensi, RI: indeks random konsistensi. Jika rasio konsistensi $\leq 0.1$, hasil perhitungan data dapat dibenarkan. Nilai indeks random konsitensi dapat dilihat pada Tabel 2.

TABEL II

DAFTAR INDEKS RANDOM KONSISTENSI

\begin{tabular}{|c|c|}
\hline Ukuran Matriks & Nilai IR \\
\hline 1,2 & 0,00 \\
\hline 3 & 0,58 \\
\hline 4 & 0,90 \\
\hline 5 & 1,12 \\
\hline 6 & 1,14 \\
\hline 7 & 1,32 \\
\hline 8 & 1,41 \\
\hline 9 & 1,45 \\
\hline 10 & 1,49 \\
\hline 11 & 1,51 \\
\hline 12 & 1,48 \\
\hline 13 & 1,56 \\
\hline 14 & 1,57 \\
\hline 15 & 1,59 \\
\hline
\end{tabular}

\section{B. Perhitungan AHP}

1. Menentukan Prioritas Kriteria. Ada 6 (enam), kriteria desa terbaik, Tabel 3:

TABEL III

KRITERIA DESA TERBAIK

\begin{tabular}{|c|l|c|}
\hline No & \multicolumn{1}{|c|}{ Nama Kriteria } & Inisialisasi \\
\hline 1 & Pendidikan masyarakat & $(\mathrm{K} 1)$ \\
\hline 2 & Kesehatan Masyarakat & $(\mathrm{K} 2)$ \\
\hline 3 & Ekonomi Masyarakat & $(\mathrm{K} 3)$ \\
\hline 4 & Keamanan dan Ketertiban & $(\mathrm{K} 4)$ \\
\hline 5 & Pemerintahan & $(\mathrm{K} 5)$ \\
\hline 6 & $\begin{array}{l}\text { Lembaga Kemasyarakatan dan } \\
\text { Pemberdayaan Kesejahteraan Keluarga } \\
(\text { PKK) }\end{array}$ & $(\mathrm{K} 6)$ \\
\hline
\end{tabular}


Rule :

a. Pendidikan sama pentingnya dengan kesehatan masyarakat, sedikit lebih penting dari ekonomi masyarakat dan keamanan dan ketertiban, dan lebih penting dari pemerintahan dan lembaga kemasyarakatan dan PKK.

b. Kesehatan masyarakat sedikit lebih penting dari ekonomi masyarakat dan keamanan dan ketertiban dan lebih penting dari pemerintahan dan lembaga kemasyarakatan dan PKK.

c. Ekonomi masyarakat sama pentingnya dengan keamanan dan ketertiban dan sedikit lebih penting dari pemerintahan desa dan lembaga kemasyarakatan dan PKK.

d. Keamanan desa sedikit lebih penting dari pemerintahan desa dan lembaga kemasyarakatan dan PKK.

e. Pemerintahan desa sama pentingnya dengan lemabag kemasyarakatan dan PKK.

2. Membuat matriks perbandingan berpasangan.

Pada tahap ini dilakukan penilaian perbandingan antara satu kriteria dengan kriteria yang lain, Tabel 4.

TABEL IV

MASUKAN NILAI PERBANDINGAN KRITERIA
\begin{tabular}{|l|l|l|l|l|l|l|}
\hline & K 1 & K 2 & K 3 & K 4 & K5 & K6 \\
\hline K1 & 1 & 1 & 3 & 3 & 5 & 5 \\
\hline K 2 & $1 / 1$ & 1 & 3 & 3 & 5 & 5 \\
\hline K 3 & $1 / 3$ & $1 / 3$ & 1 & 1 & 3 & 3 \\
\hline K 4 & $1 / 3$ & $1 / 3$ & $1 / 1$ & 1 & 3 & 3 \\
\hline K 5 & $1 / 5$ & $1 / 5$ & $1 / 3$ & 1 & 1 & 1 \\
\hline K6 & $1 / 5$ & $1 / 5$ & $1 / 3$ & $1 / 3$ & 1 & 1 \\
\hline
\end{tabular}

Angka 1 pada kolom K1 baris K1 menggambarkan tingkat kepentingan yang sama antara K1 dengan K1. Sedangkan angka 3 pada kolom K3 baris K1 menunjukan K1 sedikit lebih penting dibandingkan dengan $\mathrm{K} 3$.

TABEL V

MATRIKS NILAI PERBANDINGAN BERPASANGAN KRITERIA

\begin{tabular}{|c|l|l|l|l|l|l|}
\hline & K1 & K2 & K3 & K4 & K5 & K6 \\
\hline K1 & 1 & 1 & 3 & 3 & 5 & 5 \\
\hline K2 & 1 & 1 & 3 & 3 & 5 & 5 \\
\hline K3 & 0.333 & 0.333 & 1 & 1 & 3 & 3 \\
\hline K4 & 0.333 & 0.333 & 1 & 1 & 3 & 3 \\
\hline K5 & 0.200 & 0.200 & 0.333 & 0.333 & 1 & 1 \\
\hline K6 & 0.200 & 0.200 & 0.333 & 0.333 & 1 & 1 \\
\hline Jumlah Kolom & 3.066 & 3.066 & 8.666 & 8.666 & 18 & 18 \\
\hline
\end{tabular}

3. Membuat matriks nilai kriteria.

Matriks ini diperoleh dengan rumus: Nilai baris kolom baru = nilai baris kolom lama/jumlah masing-masing kolom lama, Tabel 6
TABEL VI

MATRIKS NILAI KRITERIA

\begin{tabular}{|l|c|c|c|c|c|c|c|c|}
\hline & $\mathrm{K} 1$ & $\mathrm{~K} 2$ & $\mathrm{~K} 3$ & $\mathrm{~K} 4$ & $\mathrm{~K} 5$ & $\mathrm{~K} 6$ & $\begin{array}{c}\text { Jlh } \\
\text { baris }\end{array}$ & $\begin{array}{c}\text { Priorita } \\
\text { s }\end{array}$ \\
\hline $\mathrm{K}$ & 0.32 & 0.32 & 0.34 & 0.34 & 0.27 & 0.27 & 1.90 & \\
1 & 6 & 6 & 6 & 6 & 8 & 8 & 0 & 0.317 \\
\hline $\mathrm{K}$ & 0.32 & 0.32 & 0.34 & 0.34 & 0.27 & 0.27 & 1.90 & \\
2 & 6 & 6 & 6 & 6 & 8 & 8 & 0 & 0.317 \\
\hline $\mathrm{K}$ & 0.10 & 0.10 & 0.11 & 0.11 & 0.16 & 0.16 & 0.78 & \\
3 & 9 & 9 & 5 & 5 & 7 & 7 & 2 & 0.130 \\
\hline $\mathrm{K}$ & 0.10 & 0.10 & 0.11 & 0.11 & 0.16 & 0.16 & 0.78 & \\
4 & 9 & 9 & 5 & 5 & 7 & 7 & 2 & 0.130 \\
\hline $\mathrm{K}$ & 0.06 & 0.06 & 0.03 & 0.03 & 0.05 & 0.05 & 0.31 & \\
5 & 5 & 5 & 8 & 8 & 6 & 6 & 8 & 0.053 \\
\hline $\mathrm{K}$ & 0.06 & 0.06 & 0.03 & 0.03 & 0.05 & 0.05 & 0.31 & \\
6 & 5 & 5 & 8 & 8 & 6 & 6 & 8 & 0.053 \\
\hline
\end{tabular}

Nilai 0,326 pada kolom K1 baris K1 Tabel 7, diperoleh dari nilai kolom Kinerja baris Kinerja Tabel 6 dibagi jumlah kolom Kinerja Tabel6, Nilai kolom jumlah pada Tabel 7 diperoleh dari penjumlahan setiap barisnya. Untuk baris pertama merupakan hasil penjumlahan dari $0.326+0.326$ $+0.346+0.346+0.278+0.278=1.900$

Nilai Kolom Prioritas diperoleh dari nilai pada kolom jumlah dibagi dengan jumlah kriteria dalam penelitian ini (1.900/6=0.317).

4. Penghitungan rasio konsistensi.

Penghitungan ini digunakan untuk memastikan bahwa nilai rasio konsistensi $(\mathrm{CR})<=0,1$. Jika ternyata nilai $\mathrm{CR}$ lebih besar dari 0,1 , maka matriks perbandingan harus diperbaiki.

TABEL VII PERHITUNGAN RASIO KONSISTENS

\begin{tabular}{|c|c|c|c|}
\hline & Jumlah Perbaris & Prioritas & Hasil \\
\hline K1 & 1.900 & 0.317 & 2.217 \\
\hline K2 & 1.900 & 0.317 & 2.217 \\
\hline K3 & 0.782 & 0.130 & 0.912 \\
\hline K4 & 0.782 & 0.130 & 0.912 \\
\hline K5 & 0.318 & 0.053 & 0.371 \\
\hline K6 & 0.318 & 0.053 & 0.371 \\
\hline \multicolumn{3}{|l}{ Jumlah } & 7.000 \\
\hline
\end{tabular}

Dari Tabel VIII diperoleh, jumlah (hasil penjumlahan dari niai-nilai hasil $)=7.000 . \mathrm{N}($ Jumlah kriteria $)=6$.

$\Lambda$ maks (jumlah $/ \mathrm{n})=7.000 / 6=1.167$

$\mathrm{CI}(\lambda$ maks-n $) / \mathrm{n}-1)=(1.167-6) / 6=-0.806$

$\mathrm{CR}=\mathrm{CI} / \mathrm{IR}(\mathrm{IR}$ lihat tabel 3.2) $=0.806 / 1.14=-0.650$

Oleh karena $\mathrm{CR}<0.1$ maka rasio konsistensi dari perhitungan tersebut dapat diterima.

5. Menentukan prioritas subkriteria

Penghitungan subkriteria dilakukan terhadap sub-sub dari semua kriteria, dalam hal ini terdapat 6 kriteria yang berarti akan terdapat 6 perhitungan prioritas subkriteria, subkriteria dari masing-masing kriteria adalah Baik, cukup, dan kurang.

6. Menghitung prioritas subkriteria dari kriteria yaitu baik, cukup dan kurang, dimana penilaian dari subkriteria dari setiap alternatif yang ditentukan:

a) Pendidikan Masyarkat (K1): Indikator penilaian dari subkriteria pendidikan masyarakat, Tabel 8: 
TABEL VIII

INDIKATOR SUBKRITERIA PENDIDIKAN MASYARAKAT

\begin{tabular}{|c|c|c|c|}
\hline $\begin{array}{l}\mathrm{N} \\
\mathrm{o}\end{array}$ & Indikator & Sub Indikator & Nila \\
\hline \multirow[t]{2}{*}{1} & \multirow{2}{*}{$\begin{array}{l}\text { Penduduk yang tidak bisa } \\
\text { baca dan tulis }\end{array}$} & Ada & 1 \\
\hline & & Tidak ada & 2 \\
\hline \multirow[t]{2}{*}{2} & \multirow{2}{*}{$\begin{array}{l}\text { Jumlah Penduduk tamat } \\
\text { SD/Sederajat }\end{array}$} & Lebih dari $1 \%$ & 1 \\
\hline & & Kurang dari $1 \%$ & 2 \\
\hline \multirow[t]{2}{*}{3} & \multirow{2}{*}{$\begin{array}{l}\text { Jumlah Penduduk tamat } \\
\text { SLTP / Sederajat }\end{array}$} & Kurang dari $1 \%$ & 1 \\
\hline & & Lebih dari $1 \%$ & 2 \\
\hline \multirow[t]{2}{*}{4} & \multirow{2}{*}{$\begin{array}{l}\text { Jumlah Penduduk tamat } \\
\text { SLTA / Sederajat }\end{array}$} & Kurang dari $1 \%$ & 1 \\
\hline & & Lebih dari $1 \%$ & 2 \\
\hline \multirow[t]{2}{*}{5} & \multirow{2}{*}{$\begin{array}{l}\text { Jumlah Penduduk tamat } \\
\text { D3/ Sarjana Muda }\end{array}$} & Kurang dari $1 \%$ & 1 \\
\hline & & Lebih dari $1 \%$ & 2 \\
\hline \multirow[t]{2}{*}{6} & \multirow{2}{*}{$\begin{array}{l}\text { Jumlah Penduduk tamat } \\
\text { Sarjana / S-1 }\end{array}$} & Kurang dari $1 \%$ & 1 \\
\hline & & Lebih dari $1 \%$ & 2 \\
\hline \multirow[t]{2}{*}{7} & \multirow{2}{*}{$\begin{array}{l}\text { Jumlah Penduduk Pasca } \\
\text { Sarjana }\end{array}$} & Kurang dari $1 \%$ & 1 \\
\hline & & Lebih dari $1 \%$ & 2 \\
\hline \multicolumn{4}{|c|}{ Total Nilai } \\
\hline
\end{tabular}

Desa yang bernilai 12-14 bernilai baik, 9-11 bernilai cukup dan dibawah 9 bernilai kurang.

b) Kesehatan Masyarakat (K2): Indikator penilaian dari subkriteria kesehatan masyarakat, Tabel 9.

TABEL IX

INDIKATOR SUBKRITERIA KESEHATAN MASYARAKAT MASYARAKAT

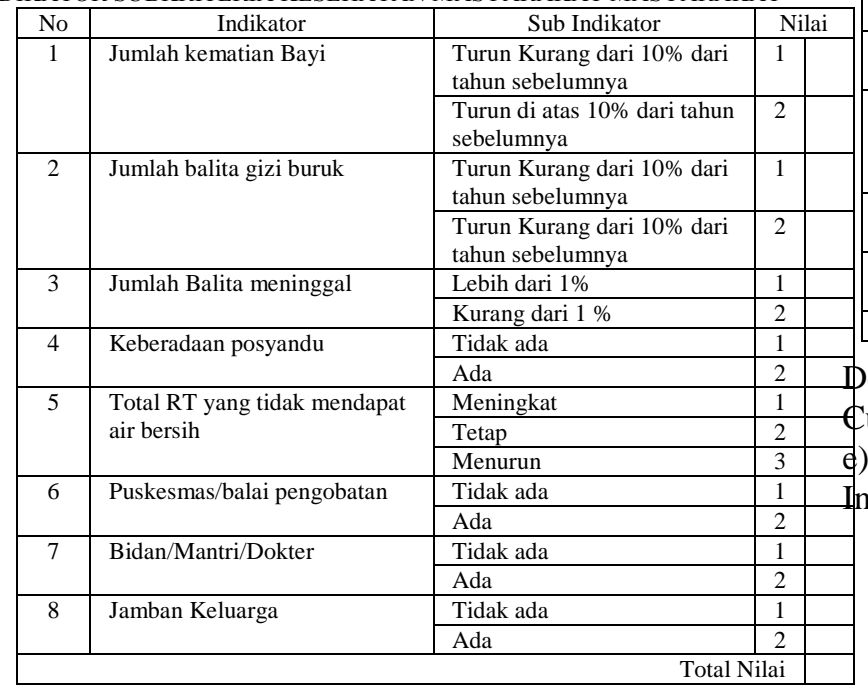

Desa yang bernilai $14-17$ bernilai baik 10-13 bernilai Cukup dan dibawah 10 Bernilai Kurang.

c) Penilaian Ekonomi Masyarakat (K3) : Indikator penilaian dari subkriteria Ekonomi masyarakat, Tabel 10 .

TABEL X

INDIKATOR SUBKRITERIA EKONOMI MASYARAKAT

\begin{tabular}{|c|c|c|c|}
\hline No & Indikator & Sub Indikator & Nilai \\
\hline \multirow[t]{2}{*}{1} & \multirow{2}{*}{$\begin{array}{l}\text { Jumlah penduduk usia } 15- \\
65 \text { tahun yang tidak bekerja }\end{array}$} & Lebih dari $10 \%$ & 1 \\
\hline & & Kurang dari $10 \%$ & 2 \\
\hline \multirow[t]{2}{*}{2} & \multirow[t]{2}{*}{ Pasar Tradisional } & Tidak ada & 1 \\
\hline & & Ada & 2 \\
\hline \multirow[t]{2}{*}{3} & \multirow[t]{2}{*}{ Toko Kios } & Tidak ada & 1 \\
\hline & & Ada & 2 \\
\hline \multirow[t]{2}{*}{4} & \multirow[t]{2}{*}{ Data masyarakat miskin } & Tidak ada & 1 \\
\hline & & Ada & 2 \\
\hline
\end{tabular}

\begin{tabular}{|c|l|l|c|c|}
\hline 5 & Program Penanggulangan & Tidak ada & 1 \\
\cline { 3 - 3 } & Kemiskinan & Ada & 2 \\
\hline \multicolumn{2}{|c|}{ Total Nilai } \\
\hline
\end{tabular}

Desa yang bernilai 8-10 bernilai baik 6-7 bernilai Cukup dan dibawah 6 Bernilai Kurang.

d) Penilaian Keamanan dan ketertiban (K4): Indikator penilaian dari subkriteria Keamanan dan ketertiban disajikan.

TABEL XI

INDIKATOR SUBKRITERIA KEAMANAN DAN KETERTIBAN

\begin{tabular}{|c|c|c|c|}
\hline No & Indikator & Sub Indikator & Nil \\
\hline \multirow[t]{2}{*}{1} & \multirow{2}{*}{$\begin{array}{l}\text { Petugas keamanan } \\
\text { lingkungan (Linmas) }\end{array}$} & Tidak ada & 1 \\
\hline & & Ada & 2 \\
\hline \multirow[t]{2}{*}{2} & \multirow[t]{2}{*}{ Konflik SARA } & Ada & 1 \\
\hline & & Tidak Ada & 2 \\
\hline \multirow[t]{2}{*}{3} & \multirow[t]{2}{*}{ Kasus Perkelahian } & Ada & 1 \\
\hline & & Tidak Ada & 2 \\
\hline \multirow[t]{2}{*}{4} & \multirow{2}{*}{$\begin{array}{l}\text { Kasus Pencurian dan } \\
\text { perampokan }\end{array}$} & Ada & 1 \\
\hline & & Tidak Ada & 2 \\
\hline \multirow[t]{2}{*}{5} & \multirow[t]{2}{*}{ Perjudian } & Ada & 1 \\
\hline & & Tidak Ada & 2 \\
\hline \multirow[t]{2}{*}{6} & \multirow{2}{*}{$\begin{array}{l}\text { Jumlah kasus narkoba } \\
\text { dengan pelaku pemrintah } \\
\text { desa }\end{array}$} & Ada & 1 \\
\hline & & Tidak Ada & 2 \\
\hline \multirow[t]{2}{*}{7} & \multirow{2}{*}{$\begin{array}{l}\text { Anggota Masyarakat yang } \\
\text { Terkena Narkoba }\end{array}$} & Ada & 1 \\
\hline & & Tidak Ada & 2 \\
\hline \multirow[t]{2}{*}{8} & \multirow{2}{*}{$\begin{array}{l}\text { Jumlah kasus prostitusi } \\
\text { dengan berbagai kasus }\end{array}$} & Ada & 1 \\
\hline & & Tidak ada & 2 \\
\hline \multirow[t]{2}{*}{9} & \multirow[t]{2}{*}{ Jumlah kasus pembunuhan } & Ada & 1 \\
\hline & & Tidak Ada & 2 \\
\hline \multirow[t]{2}{*}{10} & \multirow[t]{2}{*}{ Kekerasan dalam keluarga } & Ada & 1 \\
\hline & & Tidak ada & 2 \\
\hline \multirow[t]{2}{*}{11} & \multirow{2}{*}{$\begin{array}{l}\text { Kekerasan seksual/kasus } \\
\text { pemerkosaan }\end{array}$} & Ada & 1 \\
\hline & & Tidak ada & 2 \\
\hline \multirow[t]{2}{*}{12} & \multirow[t]{2}{*}{ Penculikan } & Ada & 1 \\
\hline & & Tidak ada & 2 \\
\hline \multirow[t]{2}{*}{13} & \multirow[t]{2}{*}{ Kasus HIV/AIDS } & Ada & 1 \\
\hline & & Tidak ada & 2 \\
\hline & & & Vilai \\
\hline
\end{tabular}

Desa yang bernilai 23-26 bernilai baik 18-22, bernilai fukup dan dibawah 18 Bernilai Kurang.

e) Penilaian Pemerintahan (K5)

dikator penilaian dari subkriteria Pemerintahan, Tabel 12.

TABEL XII

INDIKATOR SUBKRITERIA PEMERINTAHAN

\begin{tabular}{|c|c|c|c|}
\hline $\begin{array}{l}\mathrm{N} \\
\mathrm{O}\end{array}$ & Indikator & Sub Indikator & $\mathrm{N}$ \\
\hline \multirow[t]{4}{*}{1} & \multirow[t]{4}{*}{ Gedung kantor desa } & Ada dirumah pribadi & 1 \\
\hline & & Ada dirumah sewa & 2 \\
\hline & & $\begin{array}{l}\text { Ada milik pemda semi } \\
\text { permanen }\end{array}$ & 3 \\
\hline & & $\begin{array}{l}\text { Ada milik pemda } \\
\text { permanen }\end{array}$ & 4 \\
\hline \multirow[t]{3}{*}{2} & \multirow[t]{3}{*}{ Gedung pertemuan } & Tidak Ada & 1 \\
\hline & & $\begin{array}{l}\text { Ada Milik pemda semi } \\
\text { permanen }\end{array}$ & 2 \\
\hline & & $\begin{array}{l}\text { Ada milik pemda } \\
\text { permanen }\end{array}$ & 3 \\
\hline \multirow[t]{6}{*}{3} & \multirow{6}{*}{$\begin{array}{l}\text { Administrasi desa } \\
\text { 1. Administrasi Umum } \\
\text { 2.Administrasi } \\
\text { Kependudukan } \\
\text { 3.Administrasi Keuangan } \\
\text { 4.Administrasi } \\
\text { Pembangunan } \\
\text { 5.Administrasi BPDes } \\
\text { 6. Administrasi Lainnya) }\end{array}$} & Ada 1 & 1 \\
\hline & & Ada 2 & 2 \\
\hline & & Ada 3 & 3 \\
\hline & & Ada 4 & 4 \\
\hline & & Ada 5 & 5 \\
\hline & & Lengkap & 6 \\
\hline
\end{tabular}




\begin{tabular}{|c|c|c|c|}
\hline \multirow[t]{2}{*}{4} & \multirow{2}{*}{$\begin{array}{l}\text { Rasio Jumlah Pendapatan } \\
\text { Asli Desa (PADes) } \\
\text { terhadap Dana Desa } \\
\text { (DD) }\end{array}$} & $50 \%$ ke bawah & 1 \\
\hline & & Di atas $50 \%$ & 2 \\
\hline \multirow[t]{2}{*}{5} & \multirow[t]{2}{*}{ Laporan dana desa } & Tidak Ada & 1 \\
\hline & & Ada & 2 \\
\hline \multirow[t]{2}{*}{6} & \multirow{2}{*}{$\begin{array}{l}\text { Alokasi dana desa } \\
\text { (ADD) }\end{array}$} & Tidak Ada & 1 \\
\hline & & Ada & 2 \\
\hline \multirow[t]{2}{*}{7} & \multirow{2}{*}{$\begin{array}{l}\text { Hibah sumbangan dari } \\
\text { pihak ketiga }\end{array}$} & Tidak Ada & 1 \\
\hline & & Ada & 2 \\
\hline \multirow[t]{2}{*}{8} & \multirow{2}{*}{$\begin{array}{l}\text { Laporan penyaluran dan } \\
\text { realisasi penggunaan } \\
\text { Dana Desa }\end{array}$} & Tidak Ada & 1 \\
\hline & & Ada & 2 \\
\hline \multirow[t]{2}{*}{9} & \multirow{2}{*}{$\begin{array}{l}\text { Laporan pertanggungj } \\
\text { awaban APBDesa }\end{array}$} & Tidak Ada & 1 \\
\hline & & Ada & 2 \\
\hline \multirow[t]{2}{*}{10} & \multirow{2}{*}{$\begin{array}{l}\text { Bentuk laporan } \\
\text { pertanggungjawaban } \\
\text { berupa Perdes }\end{array}$} & Tidak ada & 1 \\
\hline & & Ada & 2 \\
\hline \multirow[t]{2}{*}{11} & \multirow{2}{*}{$\begin{array}{l}\text { Penyampaian laporan } \\
\text { keterangan } \\
\text { pertanggungjawaban } \\
\text { kepada BPD }\end{array}$} & Tidak ada & 1 \\
\hline & & Ada & 2 \\
\hline \multirow[t]{2}{*}{12} & \multirow{2}{*}{$\begin{array}{l}\text { Penyampaian informasi } \\
\text { kepada masyarakat } \\
\text { (terkait materi secara } \\
\text { umum). }\end{array}$} & Tidak ada & 1 \\
\hline & & Ada & 2 \\
\hline & & & ilai \\
\hline
\end{tabular}

Desa yang bernilai 24-28 bernilai baik 20-23 bernilai Cukup dan dibawah 20 Bernilai Kurang

f) Penilaian Lembaga Kemasyarakatan dan Pemberdayaan kesejahteraan keluarga (K6).

Indikator penilaian dari subkriteria pemberdayaan kesejahteraan keluarga, Tabel 13:

TABEL XIII

INDIKATOR SUBKRITERIA KEMASYARAKATAN \& PEMBERDAYAAN KESEJAHTERAAN KELUARGA

\begin{tabular}{|c|c|c|c|}
\hline No & Indikator & Sub Indikator & \\
\hline \multirow[t]{2}{*}{1} & \multirow[t]{2}{*}{ Keberadaan PKK } & Tidak ada & 1 \\
\hline & & Ada & 2 \\
\hline \multirow[t]{2}{*}{2} & \multirow[t]{2}{*}{$\begin{array}{l}\text { Realisasi } 10 \text { Program } \\
\text { Pokok }\end{array}$} & $\begin{array}{l}\text { Terealisasi } 1 \\
\text { kegiatan }\end{array}$ & 1 \\
\hline & & $\begin{array}{l}\text { Terealisasi } \\
\text { diatas } 1 \\
\text { kegiatan }\end{array}$ & 2 \\
\hline \multirow[t]{2}{*}{3} & \multirow{2}{*}{$\begin{array}{l}\text { Kelengkapan Kelompok } \\
\text { Kerja }\end{array}$} & Tidak Lengkap & 1 \\
\hline & & Lengkap & 2 \\
\hline \multirow[t]{2}{*}{4} & \multirow{2}{*}{$\begin{array}{l}\text { Kelengkapan Kelompok } \\
\text { Dasawisma }\end{array}$} & Tidak Lengkap & 1 \\
\hline & & Lengkap & 2 \\
\hline
\end{tabular}

Desa yang bernilai 7-8 bernilai baik , 5-6 bernilai Cukup dan dibawah 4 Bernilai Kurang.

7. Membuat matriks perbandingan berpasangan.

Pada tahap ini dilakukan penilaian subkriteria dari pendidikan masyarakat perbandingan antara satu sub kriteria dengan sub kriteria yang lain, Tabel 14.

TABEL XIV

MASUKAN NILAI PERBANDINGAN SUB KRITERIA

\begin{tabular}{|l|c|c|c|}
\hline & Baik & Cukup & Kurang \\
\hline Baik & 1.00 & 3.00 & 5.00 \\
\hline Cukup & $1 / 3$ & 1.00 & 3.00 \\
\hline Kurang & $1 / 5$ & $1 / 3$ & 1.00 \\
\hline
\end{tabular}

Membuat matriks perbandingan berpasangan untuk subkriteria Kinerja, langkah ini sama dengan langkah pembuatan matriks berpasangan pada tahap sebelumnya, Tabel 15.

TABEL XV

MATRIKS BERPASANGAN SUBKRITERIA KINERJA

\begin{tabular}{|l|c|c|c|}
\hline & Baik & Cukup & Kurang \\
\hline Baik & 1.000 & 3.000 & 5.000 \\
\hline Cukup & 0.333 & 1.000 & 3.000 \\
\hline Kurang & 0.200 & 0.333 & 1.000 \\
\hline Jumlah & 1.533 & 4.333 & 9.000 \\
\hline
\end{tabular}

9. Membuat matriks nilai sub kriteria.

Langkah ini sama dengan langkah pembuatan matriks berpasangan pada Tabel 5, nilai pada prioritas subkriteria diperoleh dari nilai prioritas pada baris tersebut dibagi dengan nilai tertinggi pada pada kolom prioritas, Tabel 16

TABEL XVI

MATRIKS NILAI SUBKRITERIA KINERJA

\begin{tabular}{|l|c|l|c|c|c|c|}
\hline & Baik & $\begin{array}{l}\text { Cuku } \\
\mathrm{p}\end{array}$ & $\begin{array}{l}\text { Kuran } \\
\mathrm{g}\end{array}$ & $\begin{array}{l}\text { Jumla } \\
\mathrm{h}\end{array}$ & $\begin{array}{l}\text { Priorita } \\
\mathrm{s}\end{array}$ & $\begin{array}{l}\text { Prioritas } \\
\text { Subkriteri } \\
\mathrm{a}\end{array}$ \\
\hline Baik & $\begin{array}{c}0.65 \\
2\end{array}$ & 0.692 & 0.556 & 1.900 & 0.633 & 1.000 \\
\hline Cukup & $\begin{array}{c}0.21 \\
7\end{array}$ & 0,231 & 0.333 & 0.781 & 0.260 & 0.411 \\
\hline $\begin{array}{l}\text { Kuran } \\
\mathrm{g}\end{array}$ & $\begin{array}{c}0.13 \\
0\end{array}$ & 0.077 & 0.111 & 0.318 & 0.106 & 0.167 \\
\hline
\end{tabular}

10. Membuat matriks penjumlahan setiap baris

Langkah ini sama dengan langkah pembuatan matriks berpasangan pada Tabel 6. Hasil perhitungan, Tabel 17.

TABEL XVII

PERHITUNGAN RASIO KONSISTENS

\begin{tabular}{|l|c|c|c|}
\hline & Jumlah perbaris & Prioritas & Hasil \\
\hline Baik & 1.900 & 0.63 & 1.000 \\
\hline Cukup & 0.781 & 0.26 & 0.411 \\
\hline Kurang & 0.318 & 0.11 & 0.167 \\
\hline \multicolumn{3}{|c|}{ Jumlah } & 3.998 \\
\hline
\end{tabular}

11. Perhitungan rasio konsistensi

Dari tabel 3.17 diperoleh nilai-nilai sebagai berikut: Jumlah (hasil penjumlahan dari nilai hasil) $=3.998$

$\mathrm{N}$ (jumlah kriteria) $=3$

$\Lambda$ maks (jumlah $/ \mathrm{n})=3.99=1.333$

$\mathrm{CI}((\lambda$ maks-n $) / \mathrm{n})=(1.33-3) / 3=-0.556$

$\mathrm{CR}=\mathrm{CI} / \mathrm{IR}=(-0.556) / 0.58=-0.958$

Oleh karena $\mathrm{CR}<0.1$ maka rasio konsistensi dari perhitungan tersebut bisa diterima.

12. Untuk perhitungan subkriteria

Kesehatan Masyarakat (K2), Ekonomi Masyarakat (K3), Keamanan dan Ketertiban (K4), Pemerintahan (K5), Lembaga Kemasyarakatan (K6), Pemberdayaan Kesejahteraan Keluarga (K7) dilakukan dengan cara yang sama.

\section{Menghitung Hasil}

Prioritas hasil perhitungan pada pada langkah-langkah sebelumnya (1-12), dituangkan dalam matriks, Tabel 18.

TABEL XVIII

INFORMASI NILAI PRIORITAS

\begin{tabular}{|c|c|c|c|c|c|}
\hline K1 & K2 & K3 & K4 & K5 & K6 \\
\hline 0.317 & 0.317 & 0.130 & 0.130 & 0.053 & 0.053 \\
\hline Baik & Baik & Baik & Baik & Baik & Baik \\
\hline 1 & 1 & 1 & 1 & 1 & 1 \\
\hline Cukup & Cukup & Cukup & Cukup & Cukup & Cukup \\
\hline
\end{tabular}




\begin{tabular}{|c|c|c|c|c|c|}
\hline 0.411 & 0.411 & 0.411 & 0.411 & 0.411 & 0.411 \\
\hline Kurang & Kurang & Kurang & Kurang & Kurang & Kurang \\
\hline 0.167 & 0.167 & 0.167 & 0.167 & 0.167 & 0.167 \\
\hline
\end{tabular}

Hasil penilaian Data Desa, Tabel 19.

TABEL XIX

HASIL PENILAIAN DESA

\begin{tabular}{|l|c|c|c|c|c|c|}
\hline $\begin{array}{c}\text { Nama } \\
\text { Desa }\end{array}$ & K1 & K2 & K3 & K4 & K5 & K6 \\
\hline Jati Rejo & Kurang & Baik & Cukup & Cukup & Cukup & Baik \\
\hline $\begin{array}{l}\text { Pasar } \\
\text { Miring }\end{array}$ & Baik & Baik & Baik & Baik & Cukup & Baik \\
\hline $\begin{array}{l}\text { Sukamuli } \\
\text { a }\end{array}$ & Baik & Cukup & Baik & Baik & Kurang & $\begin{array}{l}\text { Cuku } \\
\text { p }\end{array}$ \\
\hline $\begin{array}{l}\text { Purwodad } \\
\text { i }\end{array}$ & Baik & Cukup & Baik & Cukup & Cukup & $\begin{array}{l}\text { Cuku } \\
\text { p }\end{array}$ \\
\hline Sidodadi & Cukup & Kurang & Baik & Cukup & Baik & $\begin{array}{l}\text { Cuku } \\
\text { p }\end{array}$ \\
\hline $\begin{array}{l}\text { Tanjung } \\
\text { Mulia }\end{array}$ & Cukup & Baik & Cukup & Kurang & Cukup & $\begin{array}{l}\text { Cuku } \\
\text { puk }\end{array}$ \\
\hline
\end{tabular}

TABEL XX

HASIL AKHIR PERHITUNGAN AHP

\begin{tabular}{|l|l|l|l|l|l|l|l|l|}
\hline Nama & K1 & K2 & K3 & K4 & K5 & K6 & $\begin{array}{l}\text { Tota } \\
\text { l }\end{array}$ & Ket \\
\hline $\begin{array}{l}\text { Pasar } \\
\text { Miring }\end{array}$ & 0.31 & 0.31 & 0.13 & 0.13 & 0.02 & 0.05 & $\begin{array}{l}0.96 \\
9\end{array}$ & $\begin{array}{l}\text { Terbai } \\
\mathbf{k}\end{array}$ \\
\hline Sukamuli & 0.31 & 0.13 & 0.13 & 0.13 & 0.00 & 0.02 & 0.73 & - \\
a & 7 & 0 & 0 & 0 & 9 & 2 & 8 & \\
\hline Purwoda & 0.31 & 0.13 & 0.13 & 0.05 & 0.02 & 0.02 & 0.67 & - \\
di & 7 & 0 & 0 & 3 & 2 & 2 & 4 & \\
\hline Tanjung & 0.13 & 0.31 & 0.05 & 0.02 & 0.02 & 0.02 & 0.56 & - \\
Mulia & 0 & 7 & 3 & 2 & 2 & 2 & 6 & \\
\hline Jati Rejo & 0.05 & 0.31 & 0.05 & 0.05 & 0.02 & 0.05 & 0.55 & - \\
& 3 & 7 & 3 & 3 & 2 & 3 & 1 & \\
\hline Sidodadi & 0.13 & 0.05 & 0.13 & 0.05 & 0.05 & 0.02 & 0.44 & - \\
& 0 & 3 & 0 & 3 & 3 & 2 & 1 & \\
\hline
\end{tabular}

Nilai 0.137 pada kolom K1 baris Pasar Miring diperoleh dari nilai Pasar Miring untuk Pendidikan Masyarakat (K1), yaitu dengan prioritas 0.317 dikalikan dengan prioritas sub kriteria Baik 1.000. Nilai total paling tinggi dipakai sebagai dasar untuk merangking desa terbaik yaitu Desa Pasar Miring dengan Nilai Akhir $=0.969$

\section{Implementasi Sistem}

Form Data Kriteria, berfungsi untuk menginput kriteria data desa terbaik, Gambar 2. Form Data Subkriteria menginformasikan Data Desa sesuai dengan kriteria yang telah ditentukan sebelumnya, Gambar 3. Form Perbandingan Berpasangan Prioritas untuk memproses data kriteria dan juga nilai baris beserta kolom sehingga mendapatkan nilai Prioritas, Gambar 4. Form Sub perbandingan berpasangan Prioritas untuk mengetahui kualitas dari setiap desa berdasarkan kriteria yang telah ditentukan, sehingga dapat menentukan desa yang terbaik.

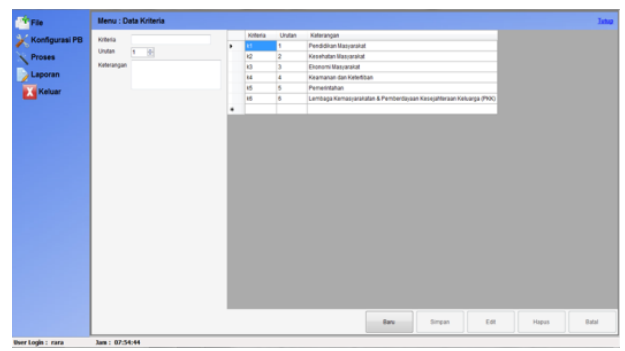

GAMBAR 2 FORM DATA KRITERIA

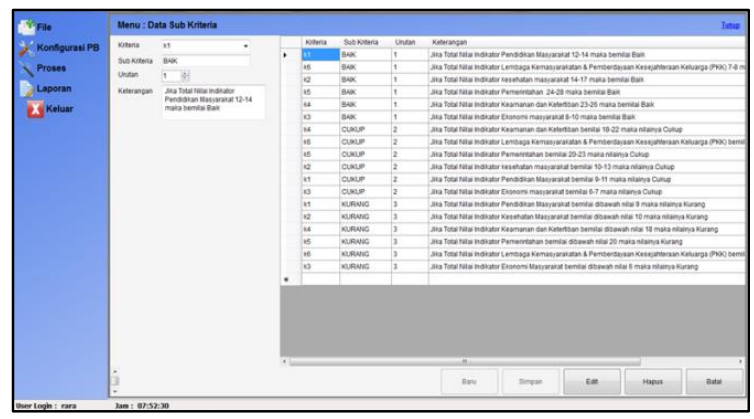

GAMBAR 3 FORM DATA SUBKRITERIA

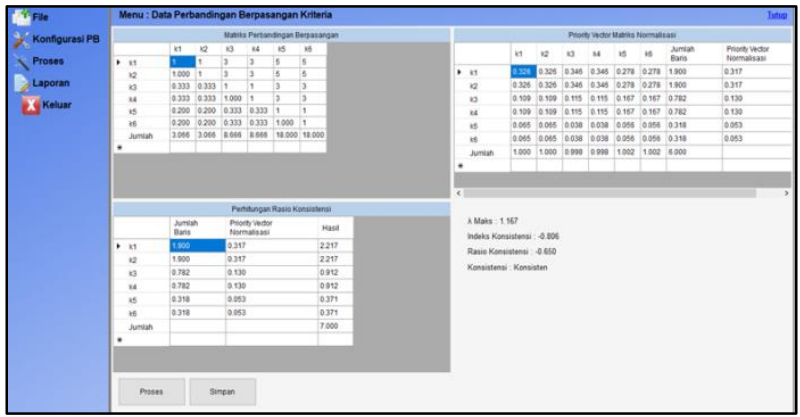

GAMBAR 4 FORM SUB PERBANDINGAN BERPASANGAN PRIORITAS

Proses pengujian sistem pendukung keputusan pemilihan desa terbaik di Kecamatan Pagar Merbau dilakukan dengan cara menguji aplikasi dengan memasukkan data ke dalam form yang telah disediakan. Pada tahap pengujian ini memungkinkan perekayasa sistem mendapatkan serangkaian kondisi input yang sepenuhnya semua persyaratan fungsional untuk suatu program sehingga kecamatan dapat menentukan desa terbaik, karena sistem program yang telah dibangun dapat berjalan semaksimal mungkin. Gambar 5. Hasil perhitungan akhir metode AHP dicetak dalam bentuk laporan, Gambar 6.

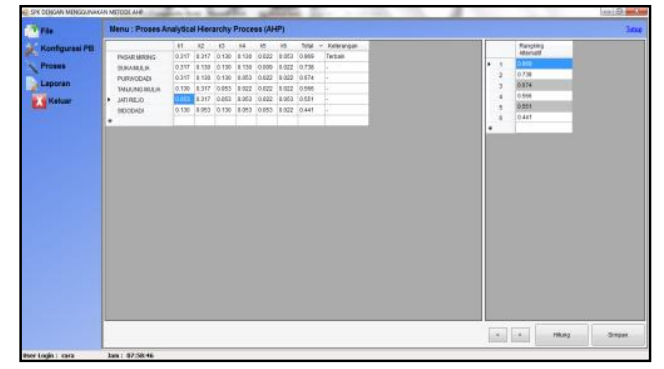

GAMBAR 5 TAMPILAN HASIL KEPUTUSAN AHP

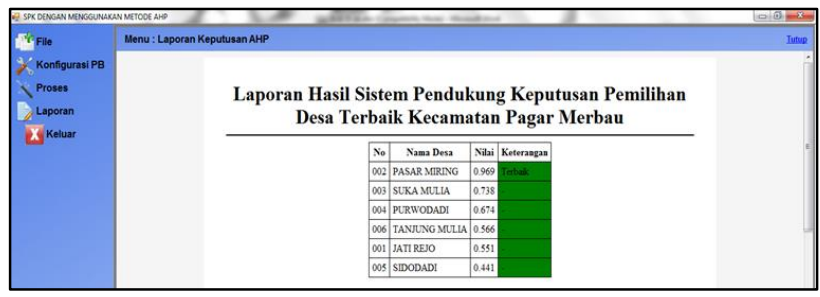

GAMBAR 6 LAPORAN HASIL KEPUTUSAN AHP 


\section{Kesimpulan}

1. Nilai total paling tinggi dari setiap baris hasil perhitungan setiap subkriteria dijumlahkan, hasil Total Nilai Paling Tinggi merupakan dasar untuk merangking desa terbaik yaitu Desa Pasar Miring dengan Nilai Akhir $=0.969$.

2. Metode AHP dapat memecahkan permasalahan yang kompleks melalui pendekatan sistem dan pengintegrasian secara deduktif sehingga pemilihan desa terbaik dapat terlaksana dengan objektif.

3. Struktur Hirarki (Hierarchy Structuring) AHP mewakili pemikiran alamiah yang cenderung mengelompokkan elemen sistem ke level-level yang berbeda dari masing-masing level berisi elemen yang serupa.

4. Keputusan AHP mempengaruhi waktu dan mengurangi terjadinya kesalahan-kesalahan serta mempercepat proses penilaian kecamatan untuk menentukan desa terbaik.

\section{Referensi}

[1] Fernandes Simangunsong, Taufiq Anshari Rasak, Kinerja Badan Pemberdayaan Masyarakat Dan Pemerintahan Desa (Bpmpd) Dalam Pelaksanaan Pemilihan Kepala Desa Serentak Melalui Metode Electronic Voting (E-Voting) Di Kabupaten Bantaeng Provinsi Sulawesi, Jurnal Ilmu Politik dan Komunikasi, Volume 06 No 1 hal:67-75, 2017.

[2] Frieyadie, Penerapan Metode AHP Sebagai Pendukung Keputusan Penetapan Beasiswa, Jurnal Pilar Nusa Mandiri Volume 13 No. 1 , hal: 49-58, Maret 2017.

[3] Wirhan Fahrozi, Penerapan Metode Analytical Hierarchy Process (AHP) dalam Menentukan Ras Ayam Serama, Citec Journal, Vol. 3, No. 3, hal: 214-227, Mei 2016 - Juli 2016

[4] Eko Darmanto, Penerapan Metode AHP (Analythic Hierarchy Process) Untuk Menentukan Kualitas Gula Tumbu, Jurnal SIMETRIS, Vol 5 No 1 hal: 75-82 April 2014.

[5] Thomson Mary, Yusran, Sistem Pendukung Keputusan Menggunakan Metode Analytic Hierarchy Process (AHP) Pemilihan Metode Pembelajaran untuk Mata Kuliah Praktikum yang Berbasiskan Bahasa Pemrograman Komputer, Jurnal Edik Informatika Penelitian Bidang Komputer Sains dan Pendidikan Informatika V1.i1(23-29) 2016.

[6] SA'ADATI, Yuan; FADLI, Sofiansyah; IMTIHAN, Khairul. Analisis Penggunaan Metode AHP dan MOORA untuk Menentukan Guru Berprestasi Sebagai Ajang Promosi Jabatan. SinkrOn, [S.1.], v. 3, n. 1, p. 82-90, sep. 2018.

[7] Daning Nur Sulistyowati, Imam Budiawan, Dwi Arum Ningtyas, Sistem Pendukung Keputusan Pemilihan Sistem Operasi Windows Pada Dekstop Dengan Menggunakan Metode Analytical Hierarchy Process, Jurnal Ilmu Pengetahuan Dan Teknologi Komputer, VOL. 3. NO. 2 hal: 175-180, Februari 2018.

[8] Kintung Prayitno, Wahyu Pujiyono, Sistem Pendukung Keputusan Dengan Pemetaan Untuk Meningkatkan Ekonomi Berbasis Industri Kecil, Jurnal Sarjana Teknik Informatika, Volume 2 Nomor 1, hal 195-206, Februari 2014. 